\title{
Job characteristics, burnout and the relationship with recovery experiences
}

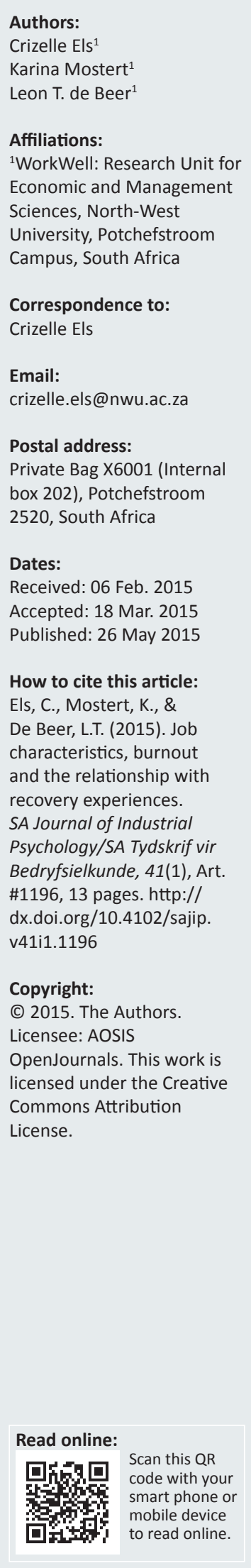

Orientation: Job characteristics (consisting of job demands and job resources) have an impact on burnout. However, it is unclear whether recovery strategies might influence this relationship amongst staff members at a tertiary education institution in South Africa.

Research purpose: The primary objective of this study was to determine whether recovery strategies influence and moderate the relationship between job demands, job resources and burnout.

Motivation for the study: Recovery strategies may influence and buffer the negative effects of job demands on burnout and may influence and enhance the positive influence of job resources on burnout.

Research approach, design and method: Cross-sectional data was collected amongst employees at a tertiary education institution $(N=366)$.

Main findings: The results of the structural equation modelling revealed significant positive relationships between work pressure, emotional demands and a lack of social support with burnout. Also, work pressure was related to all four recovery strategies and different job resources were associated with different recovery strategies. Finally, mastery experiences were the only recovery strategy that significantly predicted burnout.

Practical/managerial implications: Employees are encouraged to engage in recovery strategies that will reduce their burnout levels, especially mastery experiences.

Contribution/value-add: This study adds to the body of literature on effort recovery in South Africa. Very little empirical research has been done in South Africa regarding the use and benefits of different recovery strategies. Recommendations for future research are made.

\section{Introduction}

Research on stress-related issues can be dated back as early as the 14th century (Lumsden, 1981).

As the interest in stress progressed over the years, the importance of recovery activities to relieve day-to-day stress became evident. Because individuals invest time, effort and resources in their daily work activities, recuperation and recovery during non-work time is essential to restore energy levels. High work demands and prolonged exposure to these demands would necessitate that individual invest more effort and personal resources to meet those work demands (Meijman, 1989; Sonnentag \& Zijlstra, 2006). This would result in a need for recovery, which can be described as the subjective experience of longing for relief from regular demands and for having some time that allows for low baseline activity (Sonnentag \& Zijlstra, 2006). Recovery is a process by which an individual unwinds after spending time on work-related activities (Geurts \& Sonnentag, 2006). During a recovery period, an individual spends time away from work to prevent the depletion of personal resources and to recover (Hockey, 1996; Sonnentag \& Zijlstra, 2006; Zijlstra, 1996).

For optimal recovery, it is suggested that the recovery activities an individual engages in be adequate in terms of quantity and quality. This implies that sufficient time should be spent on activities that would allow the individual to relax and be detached from work-related worries (Van Hooff, Geurts, Kompier \& Taris, 2007). When developing the Recovery Experience Questionnaire (REQ), Sonnentag and Fritz (2007) were interested in the underlying psychological processes of recovery activities. They argued that, regardless of the activities individuals engage in, sufficient recovery would only be possible when the person experiences psychological detachment from work, relaxation, mastery and control. Insufficient recovery from work may require the need to invest extra effort at the beginning of a new working period in an attempt to reduce the negative impact of repeated insufficient recovery. Failure to invest in recovery time may result in fatigue, reduced well-being and lower performance at work (Meijman, 1989; Schroër, 1997; Sluiter, 
De Croon, Meijman \& Frings-Dresen, 2003; Sonnentag, 2003). Other negative effects of insufficient recovery include increased job stress and burnout, lower levels of work engagement and life satisfaction, as well as deterioration in mood and health. (Elfering, Grebner, Semmer \& Gerber, 2002; Etzion, Eden \& Lapidot, 1998; Jansen, Kant \& Van den Brandt, 2002; Lounsbury \& Hoopes, 1986; Meijman \& Mulder, 1998; Sonnentag, 2003; Westman \& Eden, 1997; Westman \& Etzion, 2001).

The negative effects of insufficient recovery from work and stress necessitates a closer investigation of the influence of different recovery strategies on burnout levels of individuals. As previous research has established that the interplay between job demands and job resources (collectively known as job characteristics) directly affects burnout (e.g. Bakker \& Demerouti, 2007; Bakker, Demerouti \& Euwema, 2005), the question arises as to whether recovery strategies would influence and moderate this relationship between job characteristics and burnout.

\section{Research objectives}

Based on the research problem stated above, the primary objectives of this research were (1) to determine if and which recovery strategies influence burnout and (2) to determine the moderating effect of recovery strategies on the relationship between job demands, job resources and burnout. This would guide employees to spend their leisure time on recovery activities that would truly allow them to recuperate after work.

In this article an overview of the relevant theory and literature will be presented, followed by a discussion on the research methods employed to reach the objective of this study. Next the results of this research and a discussion of these results are given. Recommendations will also be made for future research.

\section{Critical evaluation of the literature}

\section{Burnout}

During the past few decades research on burnout has been at the forefront in stress-related literature. Burnout is a stressrelated concept and is defined by Schaufeli and Enzmann (1998, p. 36) as 'a persistent, negative, work-related state of mind in "normal" individuals that is primarily characterised by exhaustion, which is accompanied by distress, a sense of reduced effectiveness, decreased motivation, and the development of dysfunctional attitudes and behaviours at work'. According to these authors burnout in the human services professions consists of three dimensions, namely emotional exhaustion, depersonalisation and a lack of personal accomplishment. However, various studies suggest that the measurement of burnout should be limited to emotional exhaustion and depersonalisation, as these dimensions are considered to constitute the core of the burnout construct (Maslach \& Jackson, 1986; Schaufeli \& Taris, 2005). According to Maslach and Jackson (1981), emotional exhaustion can be described as feelings of being emotionally overextended and exhausted by one's work, whereas depersonalisation refers to an unfeeling and impersonal response towards recipients of one's care or service. The detrimental consequences of burnout for the individual and the organisation have been widely documented and include impaired health, depression, absenteeism, intention to leave the job and actual turnover (Bakker, Demerouti, De Boer \& Schaufeli, 2003; Hakanen, Schaufeli \& Ahola, 2008; Lawson \& O’Brien, 1994; Maslach, Schaufeli \& Leiter, 2001; Price \& Spence, 1994).

\section{Job demands and job resources}

It has been established in the literature that job demands and lacking job resources are the main drivers of burnout (Llorens, Bakker, Schaufeli \& Salanova, 2006). Drawing on the Job Demands-Resources (JD-R) model, (Bakker, Demerouti, De Boer \& Schaufeli, 2003; Demerouti, Bakker, Nachreiner \& Schaufeli, 2001) job demands are the physical, psychological, social or organisational aspects of the job that require sustained cognitive or emotional effort, including high work pressure, high physical or emotional demands and cognitive demands. Work pressure refers to time pressure and workload, that is, the pace and amount of work employees are exposed to (Frone, Russell \& Cooper, 1995; Van Hooff et al., 2007). Emotional job demands refer to sustained emotional effort needed to deal with interpersonal contact (De Jonge \& Dormann, 2003; Morris \& Feldman, 1996), whereas cognitive job demands are demands related to information processing, such as having to remember many things or making quick decisions (Hockey, 2000). High job demands can be considered job stressors when effort expenditure to meet these demands is high (Meijman and Mulder, 1998) and are associated with the dimensions of burnout, including emotional exhaustion and depersonalisation (Le Blanc, Bakker, Peeters, Van Heesch \& Schaufeli, 2001).

Hypothesis 1: Job demands will be positively related to emotional exhaustion and depersonalisation.

Job resources refer to those physical, psychological, social or organisational aspects of the job that enable an individual to cope with job demands and buffer the negative effects associated with high job demands (Bakker, Demerouti, Taris, Schaufeli \& Schreurs, 2003). Examples of job resources include social support and autonomy. Social support can be described as the existence or availability of people on whom we can rely, people who let us know that they care about, value and love us (Sarason, Levine, Basha \& Sarason, 1983). Autonomy refers to the extent to which a job allows the freedom, independence and discretion to make decisions and select the methods used to perform tasks (Hackman \& Oldham, 1975). Research has shown that strong relationships exist between job resources and work engagement, organisational commitment and job satisfaction (Bakker \& Demerouti, 2007; Xanthopoulou, Bakker, Demerouti \& Schaufeli, 2009). However, previous research has revealed that the lack of job resources could also contribute to an individual's experience of burnout (Hakanen, Bakker \& Schaufeli, 2006). 
Hypothesis 2: Job resources will be negatively related to emotional exhaustion and depersonalisation.

Although Hypothesis 1 and Hypothesis 2 have been investigated and confirmed in previous studies (i.e. Cole, Walter, Bedeian \& O’Boyle, 2012; Hakanen et al., 2006; Llorens et al., 2006), it was necessary to confirm these relationships for the current study, especially since one of the objectives of this study was to test the moderating effect of recovery strategies on the relationship between job demands and job resources, and burnout.

\section{Recovery experiences}

As high job demands lead to energy depletion (Schaufeli \& Bakker, 2004) and job resources are characterised by the mobilisation of energy (Hackman \& Oldham, 1976), it becomes clear that factors such as work pressure, emotional demands and cognitive demands create a need for recovery and that social support and autonomy facilitate recovery (Hackman \& Oldham, 1976; Demerouti, Bakker, Geurts \& Taris, 2009). One theory that has dominated research on stress and recovery processes is the Effort-Recovery (ER) model by Meijman and Mulder (1998). The E-R model suggests that an individual invests effort in an attempt to meet job demands, which may in turn result in load reactions such as fatigue. During non-work time, when the individual is no longer confronted with work demands, these load reactions cease and recovery occurs. However, in the case where the individual does not distance himself from his job stressors or experience insufficient recovery after a workday, the individual may suffer physical and psychological consequences. In contrast, sufficient recovery during or after work hours allows an individual to recuperate and thus limit the negative effects of prolonged exposure to work stress (Meijman \& Mulder, 1998).

Relationships between various job demands and the need for recovery have been established in the literature. Empirical research has shown when exposed to job stressors (e.g. work pressure and overload) an individual draws on his resources and exerts extra effort to meet these demands (Hockey, 1996; Zohar, Tzischinski \& Epstein, 2003). This exposure to high work demands and the extra effort expenditure needed to cope with these demands result in the experience of fatigue and exhaustion. This would necessitate sufficient recovery in terms of quantity (time) and quality (type of recovery activities) to restore personal resources and combat the negative effects of work pressure (De Croon, Sluiter, Blonk, Broersen \& Frings-Dresen, 2004; Eden, 2001; Meijman \& Mulder, 1998; Sluiter, Van der Beek \& Frings-Dresen, 1999; Sonnentag \& Zijlstra, 2006).

Drawing on the E-R model, the Conservation of Resources theory and the mood regulation strategies of Parkinson and Totterdell (1999), Sonnentag and Fritz (2007) have developed the REQ. The rationale of the REQ is to determine the underlying processes of the activities individuals engage in during their leisure time in an attempt to recover from their work stress. Considering the above, Sonnentag and Fritz included four dimensions in the mentioned questionnaire, namely psychological detachment, relaxation, mastery and control.

According to Sonnentag and Fritz (2007), detachment from work and relaxation-oriented diversion strategies outlined by Parkinson and Totterdell (1999) could contribute to recovery since these strategies imply that an individual would regulate the amount of effort spent during the workday. Psychological detachment from work, as described by Etzion et al. (1998), refers to 'the individual's sense of being away from the work situation' (p. 579). Thus, being psychologically detached implies that an individual is no longer mentally preoccupied with job-related problems and thoughts during off-job time. Failure to achieve respite from job demands could negatively influence an individual's recovery from stress and ultimately hinders well-being. Similarly, relaxation strategies could support the recovery process as they buffer the effect of stress and stimulate a positive mood (Carlson \& Holye, 1993; Sonnentag \& Fritz, 2007; Stone, KennedyMoore \& Neale, 1995; Van der Klink, Blonk, Schene \& Van Dijk, 2001). Activities individuals engage in for the purpose of relaxation include muscle relaxation (Jacobson, 1938), meditation (Grossman, Niemann, Schmidt \& Walach, 2004), exercising (Hartig, Evans, Jamner, Davis \& Gärling, 2003) and listening to music (Pelletier, 2004).

Sonnentag and Fritz (2007) also propose that mastery strategies would facilitate recovery from stress as an individual attempts to create new internal resources (e.g. self-efficacy). According to Pearlin and Schooler (1978) mastery can be described as the extent to which a person believes they are in control of their life and have the ability to control significant events in their life. Similarly, Burger (1989) defines mastery as the 'perceived ability to significantly alter events' (p. 246). Through mastery experiences an individual acquires the skills to cope with stressors over which they have no control. Research has shown that mastery is positively correlated with positive affect and negatively correlated with negative affect (Ben-Zur, 2002; Parkinson \& Totterdell, 1999; Shin, Han \& Kim, 2007). Also, Ben-Zur (2002) suggests that mastery is related to coping as it may strengthen the use of problemsolving type of strategies through the belief that things can be managed or changed, leading to images of plans and possible actions that can help in managing the stressful situation.

According to Hobfoll (1998), for an individual to gain additional resources, the experience of control is essential. Sonnentag and Fritz (2007) thus suggest that control during leisure time be included in a measure of recovery experiences. Control refers to the extent to which an individual believes that life events and circumstances can be influenced by their personal choices and actions (Rotter, 1966; Seeman, 1983). A sense of control has proven to positively influence coping with stress, since the individual believes that they can control the outcomes of stressful events (Bandura, 1977, 1986; Peterson \& Seligman, 1984; Schulz \& Heckhausen, 
1996; Shapiro, Schwartz \& Astin, 1996; Taylor, 1983; Taylor \& Brown, 1988; Thompson \& Spacapan, 1991; Weiner \& Kukla, 1970).

Sonnentag and Fritz (2007) also investigated the relations between the aforementioned recovery experiences and a set of potential predictors and consequences of these recovery experiences. Their research showed negative correlations between job demands (i.e. time pressure, role ambiguity, situational constraints and hours of overtime) and recovery experiences, and positive correlations between job control and recovery experiences. Also, as previously argued, the relationships between job demands (work pressure, emotional job demands and cognitive job demands) and job resources (autonomy and social support) and burnout have been established in the literature. However, the role of recovery experiences, and specifically as a moderator, in the relationship between job demands, job resources and burnout, has been largely unexplored.

\section{Job demands, job resources and recovery experiences}

Individuals experiencing high work pressure, especially high workload, tend to think and ruminate about work-related issues even in their non-work time (Brosschot, Gerin \& Thayer, 2006; Sonnentag \& Bayer, 2005). This suggests that these individuals would find it difficult to psychologically detach from their work. This is confirmed in a recent study by Sonnentag, Kuttler and Fritz (2010), who found that high emotional demands at work also cause difficulties in psychological detachment after work. It can also be expected that high cognitive job demands would inhibit one's ability to detach from work. Sonnentag and Fritz (2007) have also found a negative relation between job stressors and relaxation experiences. Stressors such as experiencing a high workload (cognitive and emotional) and work pressure could thus be expected to be negatively correlated with relaxation. Prolonged exposure to stress during working hours could lead to increased heart rate and high blood pressure (Vrijkotte, Van Doornen \& De Geus, 2000). This could prevent one from relaxing after work.

Work pressure and workload (cognitive and emotional) could be negatively related to mastery experiences. Sonnentag and Fritz (2007) argue that because activities that result in mastery experiences require a certain degree of effort and self-regulation, job stressors and associated fatigue will make it less likely to experience mastery off the job because it is more difficult to initiate and uphold the respective activities. It is well known that high job demands induce fatigue and exhaustion. Thus, low energy levels as a result of high job demands could lead to individuals refraining from mastery activities during their leisure time. The same holds true for control during leisure time. After expending effort and energy on high job demands and work pressure, one has low energy resources available for decision-making and control during non-work time (Sonnentag \& Fritz, 2007). Thus, it is expected that work pressure, cognitive demands and emotional demands would be negatively related to control.
Hypothesis 3: Job demands will be negatively related to all four recovery strategies.

Social support and autonomy are two job resources that foster a positive affect (Deci \& Ryan, 2000; Neely et al., 2006; Sheldon \& Elliot, 1999). In turn, positive affect could promote psychological detachment from work (Kinnunen, Feldt, Siltaloppi \& Sonnentag, 2011). Therefore, it is suggested that social support and autonomy would be positively related to psychological detachment. In addition, it may also be possible that high job resources increase a person's positive thoughts about their job, which in turn may assist in recovery from stress during leisure time (Binnewies, Sonnentag \& Mojza, 2009). Also, Demerouti et al. (2001) suggest that sufficient job resources are associated with reduced stress levels. It is reasonable to expect that these reduced stress levels would allow an individual to unwind after work (Lovibond \& Lovibond, 1996) and therefore it is expected that social support and autonomy would be positively related to relaxation.

Hobfoll (2001) suggests that resources are associated with higher levels of motivation and well-being. This increased motivation and well-being, as a result of having sufficient job resources such as social support and autonomy, could inspire an individual to engage in mastery activities during their leisure time, as they would be motivated to build their personal resources such as skills, competencies and self-efficacy (Bandura, 1997; Hobfoll, 1998). It can thus be expected that job resources would be positively related to mastery experiences. Lastly, it is expected that job resources would be positively associated with control during leisure time. Sonnentag and Fritz (2007) argue that the experience of control during leisure time may satisfy one's desire for control by increasing self-efficacy and feelings of competence. Once again, the motivational consequences derived from having job resources (Hobfoll, 2001) such as social support and autonomy could lead to individuals striving for self-efficacy and competence.

Hypothesis 4: Job resources will be positively related to all four recovery strategies.

\section{Recovery experiences and burnout}

Prolonged exposure to stressors is associated with negative effects, including exhaustion (González-Romá, Schaufeli, Bakker \& Lloret, 2006) and depersonalisation (Taris, Peeters, Le Blanc, Schreurs \& Schaufeli, 2001). The strain accumulated during the workday due to unfavourable work conditions leaves these individuals drained making it difficult for them to psychologically detach from their work, to relax, engage in mastery activities and to exercise control during their leisure time. Also, previous research has confirmed that the four recovery strategies are related to job exhaustion (Kinnunen et al., 2011; Sonnentag \& Fritz, 2007). It can also be argued that insufficient recovery from daily stressors may result in negative affect (Sonnentag, Binnewies \& Mojza, 2008). Similarly, Fritz, Sonnentag, Spector and McInroe (2010) have found that psychological detachment, relaxation, mastery 
experiences and control during leisure time are associated with positive affective states, which in turn are associated with lower depersonalisation (Denollet \& De Vries, 2006).

Based on the above discussion, it can be expected that recovery experiences will be negatively related to exhaustion and depersonalisation. However, little is known about the relationship between recovery experiences and depersonalisation. Also, the relationship between recovery strategies and burnout has also not been extensively researched in South Africa.

Hypothesis 5: All four recovery strategies will be negatively related to exhaustion and depersonalisation.

\section{The moderating role of recovery experiences}

To conclude the hypothesised relationships outlined in the literature review above, we expected that all four recovery experiences would play moderating roles in the relationship between job demands, job resources and burnout. For example, a study by Siltaloppia, Kinnunen and Feldt (2009) examined the moderating role of recovery experiences in the relationship between psychosocial work characteristics and occupational well-being. Their results suggest that relaxation moderated the relationship between time demands and job exhaustion. Furthermore, Halbesleben, Wheeler and Paustian-Underdahl (2013) found that the negative impact of the stress experienced by employees due to furloughs (i.e. the placement of employees on leave with no salary of any kind) on exhaustion was lessened when they engaged in positive recovery experiences. Various studies have found the buffering effect of psychological detachment in the stressor-strain relationship (Sonnentag, Binnewies \& Mojza, 2010; Sonnentag \& Fritz, 2014; Sonnentag, Unger \& Nägel, 2013). Relaxation as a recovery strategy has also been found to moderate the relationship between impersonal conflict and well-being (Demsky, 2012) and between job insecurity and need for recovery (Kinnunen, Mauno \& Siltaloppi, 2010).

These significant results from previous research paved the way for the possibility to explore other recovery experiences as possible moderators between other job demands and burnout. Due to the unique nature of each of the four recovery strategies, it is expected that each of these strategies may have a distinctive role to play in the stressor-strain relationship. For example, one can expect that time pressure will have a different relationship with mastery experiences, which may be time consuming, than it would have with psychological detachment, which is not necessarily reliant on time. Also, one can suppose that mastery experiences would be more exhausting for some people (since one invests energy in learning something new) than psychological detachment, which does not drain one's energy. This example clarifies the interest in the unique role each of the four recovery strategies would play in the relationship between job demands and burnout.

Hypothesis 6: All four recovery strategies moderate the relationship between job characteristics and burnout.

\section{Research design Research approach}

A cross-sectional survey design was used to reach the research objectives. Cross-sectional designs entail the collection of data on more than one case at a single point in time, after which the data is examined to detect patterns of association (Bryman \& Bell, 2003).

\section{Research method \\ Research participants}

The study population was selected on the basis of availability and consisted of employees at a tertiary institution in North-West $(N=366)$. A total of 650 questionnaires were distributed, of which 366 were returned (response rate $=$ $56 \%)$. The majority of the participants were White $(80.35 \%)$, but African (14.75\%), Indian (3.00\%) and mixed-race $(0.80 \%)$ employees also participated in the study. Males comprised $34.70 \%$ and females $65.00 \%$ of the sample. The majority of participants worked in academic faculties as either academic staff $(45.36 \%)$ or administrative staff $(53.28 \%)$, within the faculties of Health Sciences (13.39\%), Natural Sciences $(11.46 \%)$, Education (10.38\%), Engineering (9.58\%), Arts (6.83\%), Economic and Management Sciences (6.56\%) and Theology (2.70\%). Academic and administrative personnel were included, with $9.84 \%$ lecturers, $11.46 \%$ senior lecturers, $7.10 \%$ professors, $27.88 \%$ administrative assistants and $25.68 \%$ working in the administration office. The majority of participants had postgraduate degrees $(47.81 \%)$, whilst other participants possessed university degrees $(12.57 \%)$, technical college diplomas $(6.00 \%)$, technicon diplomas $(8.20 \%)$ or Grade 12 certificates (19.95\%).

\section{Measuring instruments}

Job demands: All three job demands were measured on a four-point Likert scale ranging from 0 (never) to 3 (always). Work pressure refers to the quantitative aspects of the job and was measured with three items (e.g. 'How often does it happen that you have too much work to do?'). Emotional demands were assessed with four items (e.g. 'How often does it happen that your work is emotionally draining?'). The work pressure and emotional demands scales were developed by Bakker, Demerouti and Schaufeli (2003). Cognitive demands were measure with four items (e.g. 'How often does it happen that your work is emotionally draining?') developed by M.C.W. Peeters, Montgomery, Bakker and Schaufeli (2005).

Job resources: The two job resources were measured on a four-point Likert scale ranging from 0 (never) to 3 (always). Social support was measured with three items (e.g. 'How often does it happen that you can, if necessary, ask your colleagues for help?') from a scale developed by Bakker, Demerouti and Verbeke (2004). Autonomy was assessed with three items (e.g. 'How often does it happen that you have freedom in carrying out your work-related duties?') also from the scale developed by Bakker et al. 
Recovery experiences: The four recovery experiences were measured with the REQ developed by Sonnentag and Fritz (2007). The dimensions were measured on a five-point Likert scale ranging from 1 (strongly disagree) to 5 (strongly agree). Psychological detachment was measured with four items (e.g. 'When I am not at work I do not think about work at all'), relaxation with four items (e.g. 'When I am not at work I use the time to relax'), mastery with four items (e.g. 'When I am not at work I do things that challenge me') and control with four items (e.g. 'When I am not at work I determine for myself how I will spend my time').

Burnout: Burnout was measured with the Maslach Burnout Inventory - Human Services Survey (Maslach \& Jackson, 1986), utilising a seven-point Likert scale ranging from 0 (never) to 6 (every day). Six items were used to measure emotional exhaustion (e.g. 'I feel emotionally drained by my work') and depersonalisation was measured with six items (e.g. 'I feel I treat some recipients as if they were impersonal objects').

\section{Research procedure}

Permission was granted by the university's Ethics Committee. Thereafter, lists were obtained from the various faculties and departments. Questionnaires were distributed to the selected employees with the help of fieldworkers. In the questionnaires a letter was included that explained the goal and importance of the study. Participants were assured that information will be handled with anonymity and confidentiality at all times. Participants were given two to three weeks to complete the questionnaires. After completion, participants could return the questionnaires via internal post or personal delivery. Questionnaires were also personally collected if not received by internal post.

\section{Statistical analysis}

Structural equation modelling (SEM) methods were implemented with Mplus 7.0 (Muthén \& Muthén, 2012), using the maximum likelihood estimator, to test the hypotheses. The input type was the covariance matrix. Item parcelling methods were not used, and no error terms between dependent variables were forced to correlate in the syntax. The following four fit indices were considered: comparative fit index (CFI), Tucker-Lewis index (TLI), root mean square error of approximation (RMSEA), and standardised root mean square residual (SRMR). Acceptable fit for CLI and TLI is considered at 0.90 or above (Hoyle, 1995). Browne and Cudeck (1992) suggest that for RMSEA a value of 0.05 or less indicates good fit, but that values equal to or below 0.08 should also be considered as acceptable model fit. Furthermore, for the SRMR a value below 0.08 should be considered acceptable (Hu \& Bentler, 1998). Research has suggested that the above cut-off points should only be considered as rough guidelines (cf. Marsh, 2007; Marsh, Hau \& Grayson, 2005). The overall level of statistical significance is set at $p$ less than 0.05 , and for correlation coefficients an absolute value of 0.30 or above for $r$ for indication of practical significance. To test the possible moderating effects of the recovery experiences, interaction terms were created between the individual recovery experiences and job characteristics. These defined interaction terms were then regressed on the dependent variables in the analysis to ascertain statistical significance. Any significant interactions were plotted on an two-way unstandardised interaction plot template to visually represent the effects and for ease of interpretation.

\section{Results}

Model information from the SEM analysis presented the following fit indices for the research model: CFI (0.92), TLI (0.91), RMSEA (0.05) and SRMR (0.05). This indicated that the model fit the data acceptably.

The results of the correlation coefficients and reliability are reported in Table 1.

The results suggest that the instruments used to measure all the constructs were reliable ( $\mathrm{a} \geq 0.70 ; \omega \geq 0.70$; Raykov, 2012; Sijtsma, 2009). The correlation matrix reveals that the directionality of the correlations were in accordance with what was expected from the literature, (i.e. the job resources were all negatively correlated with the job demands). Exhaustion and depersonalisation were positively

TABLE 1: Correlation matrix of the latent variables $(N=366)$.

\begin{tabular}{|c|c|c|c|c|c|c|c|c|c|c|c|c|c|}
\hline \multirow[t]{2}{*}{ Variable name } & \multicolumn{13}{|c|}{$r$} \\
\hline & $\alpha$ & $\omega$ & 1 & 2 & 3 & 4 & 5 & 6 & 7 & 8 & 9 & 10 & 11 \\
\hline 1. Work pressure & 0.82 & 0.86 & - & - & - & a & - & - & - & - & - & - & - \\
\hline 2. Emotional load & 0.86 & 0.89 & $0.58^{* \mathrm{~b}}$ & - & - & - & - & - & - & - & - & - & - \\
\hline 3. Cognitive demands & 0.71 & 0.79 & $0.59 * b$ & $0.34 * a$ & - & - & - & - & - & - & - & - & - \\
\hline 4. Autonomy & 0.67 & 0.74 & $-0.20 *$ & $-0.28 *$ & $0.05 *$ & - & - & - & - & - & - & - & - \\
\hline 5. Support & 0.75 & 0.82 & $-0.35^{* a}$ & $-0.44^{* a}$ & $-0.12 *$ & $0.60 * \mathrm{~b}$ & - & - & - & - & - & - & - \\
\hline 6. Exhaustion & 0.91 & 0.93 & $0.64 * b$ & $0.63 * b$ & $0.31 * a$ & $-0.33^{* a}$ & $-0.46 * a$ & - & - & - & - & - & - \\
\hline 7. Depersonalisation & 0.69 & 0.72 & $0.57 * \mathrm{~b}$ & $0.65 * b$ & $0.17 *$ & $-0.31^{* a}$ & $-0.43 * a$ & $0.81 * \mathrm{~b}$ & - & - & - & - & - \\
\hline 8. Control & 0.87 & 0.89 & $-0.38 * a$ & -0.32 *a & $-0.07^{*}$ & $0.44 * a$ & $0.38^{* a}$ & $-0.40 * a$ & $-0.34 * a$ & - & - & - & - \\
\hline 9. Mastery & 0.88 & 0.90 & $-0.26 *$ & $-0.28 *$ & 0.01 & $0.36^{* a}$ & $0.29 *$ & $-0.43^{* a}$ & $-0.37 * a$ & $0.71 * b$ & - & - & - \\
\hline 10. Detachment & 0.84 & 0.90 & $-0.41 * a$ & $-0.30 * a$ & $-0.22 *$ & $0.26 *$ & $0.39 * a$ & $-0.27 * a$ & $-0.17 *$ & 0.48 *a & $0.30 * a$ & - & - \\
\hline 11. Relaxation & 0.86 & 0.87 & $-0.47 * a$ & $-0.33^{* a}$ & $-0.21 *$ & $0.37 * a$ & $0.39 * a$ & $-0.42 * a$ & $-0.30 * a$ & $0.79 * b$ & $0.74^{* b}$ & $0.66 * \mathrm{~b}$ & - \\
\hline
\end{tabular}

*, statistically significant

a, medium practical significance

$\stackrel{b}{b}$ large practical significance 
correlated with job demands, but negatively correlated with job resources and recovery experiences. The job resources were positively correlated with the recovery experiences. Conversely, the job demands were negatively related to all of the recovery experiences. Furthermore, exhaustion and depersonalisation were highly correlated ( $r=0.81)$, as these two variables were the components measured for job burnout. Some readers may have concerns about the high correlation between exhaustion and depersonalisation ( $r$ $=0.81$ ). However, as these are the indicators for burnout and the correlation was not greater than 0.90 , which would evoke the possibility of discriminant validity concerns between the constructs, it was deemed acceptable to continue with reporting results for the purposes of the study. Moreover, variance inflation factors (VIF) were calculated to investigate potential multicollinearity in the model based on this high correlation: the VIF for exhaustion was 2.38 and for depersonalisation 2.43, well below the maximum cut-off values of 4.0 (Pan \& Jackson, 2008) and 5.0 (Rogerson, 2001).

Table 2 presents the structural relationships between the job characteristics and the components measured for burnout.

Concerning the paths between job demands with exhaustion and depersonalisation, work pressure was the job demand with the largest effect on both burnout dimensions ( $\beta=$ 0.43 for exhaustion; $\beta=0.46$ for depersonalisation). This partly confirms Hypothesis 1. However, interestingly, cognitive demands was not significantly associated with exhaustion in this sample, but was negatively associated with depersonalisation. In this sample, the only significant result for the job resources was the negative association of support with exhaustion $(\beta=-0.15)$. This result partly confirms Hypothesis 2.

Table 3 presents the structural relationships between the job characteristics, the recovery experiences and also the relationship between the recovery experiences and burnout.

Hypothesis 3 was also partly confirmed in that the only job demand that was positively associated with the recovery experience was work pressure; emotional load had no associations. However, cognitive demands had a positive relationship to the recovery experience of mastery $(\beta=0.20)$. Regarding the job resources and the recovery experiences, autonomy had significantly positive associations with control $(\beta=0.33)$, mastery $(\beta=0.29)$, and relaxation $(\beta=$ 0.23 ). Autonomy did not have a significant association with detachment; but support did have a significant association to detachment $(\beta=0.25)$. These results partly confirm Hypothesis 4.

The only significant relationship between the recovery experiences and the components of burnout was between mastery and exhaustion $(\beta=-0.27)$ and between mastery and depersonalisation $(\beta=-0.27)$. This indicates that mastery and burnout are negatively related. Therefore, Hypothesis 5 is only partly confirmed.

In terms of the potential interaction effects between the recovery experiences with demands in their relationship to the outcome variables, there were four significant moderating effects in this sample (see Figure 1): (1) mastery's moderating effect in the relationship between emotional load and exhaustion, indicating that employees with higher emotional load and low mastery had higher levels of exhaustion, but no real effect was apparent for high or low emotional load when mastery was high, (2) mastery's moderating effect in the relationship between work pressure and exhaustion, indicating that employees with higher work pressure and low mastery had higher exhaustion levels, but no real effect was present for low or high work pressure when mastery was high, (3) control's moderating effect in the relationship between work pressure and exhaustion, indicating that for employees with higher work pressure and low control exhaustion levels were higher, but no real effect was present for low or high work pressure when control was high, and (4) control's moderating effect in the relationship between work pressure and depersonalisation, indicating that when work pressure is high and control is low employees have higher levels of depersonalisation, but once again no real effect was present for low or high work pressure when mastery was high (see Figure 1). This provided partial support for Hypothesis 6.

TABLE 2: Structural relationships of job characteristics with burnout.

\begin{tabular}{|c|c|c|c|c|}
\hline Path relationships & Beta coefficient $(\beta)$ & Standard error & Statistical significance $(p)$ & Result \\
\hline \multicolumn{5}{|l|}{ Job demands and burnout } \\
\hline Work pressure $\rightarrow$ Exhaustion & 0.43 & 0.08 & 0.001 & Significant \\
\hline Emotional load $\rightarrow$ Exhaustion & 0.29 & 0.06 & 0.001 & Significant \\
\hline Cognitive demands $\rightarrow$ Exhaustion & -0.02 & 0.07 & 0.722 & Not significant \\
\hline Work pressure $\rightarrow$ Depersonalisation & 0.46 & 0.11 & 0.001 & Significant \\
\hline Emotional load $\rightarrow$ Depersonalisation & 0.40 & 0.08 & 0.001 & Significant \\
\hline Cognitive demands $\rightarrow$ Depersonalisation & -0.19 & 0.09 & 0.040 & Significant \\
\hline \multicolumn{5}{|l|}{ Job resources and burnout } \\
\hline Autonomy $\rightarrow$ Exhaustion & -0.04 & 0.07 & 0.617 & Not significant \\
\hline Support $\rightarrow$ Exhaustion & -0.15 & 0.07 & 0.030 & Significant \\
\hline Autonomy $\rightarrow$ Depersonalisation & -0.01 & 0.10 & 0.924 & Not significant \\
\hline Support $\rightarrow$ Depersonalisation & -0.14 & 0.10 & 0.150 & Not significant \\
\hline
\end{tabular}


TABLE 3: Structural relationships between job characteristics and recovery experiences, and between recovery experiences and burnout.

\begin{tabular}{|c|c|c|c|c|}
\hline Path relationships & Beta coefficient $(\beta)$ & Standard error & Statistical significance $(p)$ & Result \\
\hline \multicolumn{5}{|c|}{ Job demands and recovery experiences } \\
\hline Work pressure $\rightarrow$ Control & -0.36 & 0.09 & 0.001 & Significant \\
\hline Emotional load $\rightarrow$ Control & -0.05 & 0.08 & 0.553 & Not significant \\
\hline Cognitive demands $\rightarrow$ Control & 0.15 & 0.08 & 0.074 & Not significant \\
\hline Work pressure $\rightarrow$ Detachment & -0.27 & 0.10 & 0.005 & Significant \\
\hline Emotional load $\rightarrow$ Detachment & 0.01 & 0.08 & 0.930 & Not significant \\
\hline Work pressure $\rightarrow$ Mastery & -0.28 & 0.10 & 0.004 & Significant \\
\hline Emotional load $\rightarrow$ Mastery & -0.13 & 0.08 & 0.114 & Not significant \\
\hline Cognitive demands $\rightarrow$ Mastery & 0.20 & 0.09 & 0.020 & Significant \\
\hline Work pressure $\rightarrow$ Relaxation & -0.43 & 0.09 & 0.001 & Significant \\
\hline Emotional load $\rightarrow$ Relaxation & 0.02 & 0.08 & 0.828 & Not significant \\
\hline Cognitive demands $\rightarrow$ Relaxation & 0.04 & 0.08 & 0.622 & Not significant \\
\hline \multicolumn{5}{|c|}{ Job resources and recovery experiences } \\
\hline Support $\rightarrow$ Control & 0.06 & 0.09 & 0.541 & Not significant \\
\hline Autonomy $\rightarrow$ Detachment & 0.06 & 0.09 & 0.487 & Not significant \\
\hline Support $\rightarrow$ Detachment & 0.25 & 0.09 & 0.006 & Significant \\
\hline Autonomy $\rightarrow$ Mastery & 0.29 & 0.10 & 0.003 & Significant \\
\hline Support $\rightarrow$ Mastery & -0.02 & 0.10 & 0.873 & Not significant \\
\hline Autonomy $\rightarrow$ Relaxation & 0.23 & 0.09 & 0.120 & Significant \\
\hline Support $\rightarrow$ Relaxation & 0.11 & 0.09 & 0.238 & Not significant \\
\hline \multicolumn{5}{|l|}{ Recovery experiences and burnout } \\
\hline Control $\rightarrow$ Exhaustion & 0.02 & 0.09 & 0.862 & Not significant \\
\hline Detachment $\rightarrow$ Exhaustion & 0.08 & 0.08 & 0.312 & Not significant \\
\hline Mastery $\rightarrow$ Exhaustion & -0.27 & 0.09 & 0.003 & Significant \\
\hline Relaxation $\rightarrow$ Exhaustion & 0.08 & 0.14 & 0.551 & Not significant \\
\hline Control $\rightarrow$ Depersonalisation & -0.03 & 0.13 & 0.836 & Not significant \\
\hline Detachment $\rightarrow$ Depersonalisation & 0.11 & 0.10 & 0.306 & Not significant \\
\hline
\end{tabular}

\section{Discussion}

The primary objectives of this research were to determine the influence of recovery strategies on burnout and, in addition, the moderating effect of recovery strategies on the relationship between job characteristics and burnout. Several hypotheses were formulated and tested to reach this objective.

Hypothesis 1 proposed that job demands are positively related to emotional exhaustion and depersonalisation. This hypothesis was partially confirmed; the results suggest that work pressure and emotional demands predict both exhaustion and depersonalisation. This is in line with the results of previous research, which has found that job demands are the main contributors to burnout. Evers and Tomic (2003) found that Dutch pastors who reported experiencing high pressure at work had high scores on emotional exhaustion and depersonalisation. Similarly, a study by Van Vegchel, De Jonge, Söderfeldt, Dormann and Schaufeli (2004) in Sweden revealed that emotional demands significantly contribute to emotional exhaustion and depersonalisation. This is explained by the notion that prolonged exposure to work strain may lead to increased levels of burnout (Meijman \& Mulder, 1998; Sluiter et al., 1999). However, cognitive demands was a significant predictor of depersonalisation, but did not predict exhaustion. This lacking relationship between cognitive demands and emotional exhaustion was also found in a study by Martin (2010) amongst teachers, as well as in the findings by Bakker, Demerouti and Schaufeli (2005) in a study of different occupations. The data of our study was collected amongst personnel at a tertiary institution and an argument can be made that cognitive demands might not deplete academics' energy, as they have an inherent need for intellectual challenge and stimulation, which they receive due to the nature of their work.

Hypothesis 2 stated that job resources will be negatively related to emotional exhaustion and depersonalisation. The results suggest that Hypothesis 2 was partially confirmed. Autonomy was not a significant predictor of exhaustion or depersonalisation. This is in contrast with the results of previous studies (Bakker, Van Der Zee, Lewig \& Dollard, 2006; Cordes, Dougherty \& Blum, 1997; Peeters \& Rutte, 2005). However, a study by A.G. Peeters and Rutte (2005) amongst primary educators also found that autonomy is not associated with lower levels of exhaustion. Similarly, in a study of social workers, Kim and Stoner (2008) also failed to prove a direct relationship between autonomy and burnout (i.e. emotional exhaustion, depersonalisation and professional efficacy). Social support did not predict depersonalisation, but it was significantly associated with lower exhaustion levels. It can be argued that support from colleagues may allow employees to save their energy, since they know they can count on their colleagues for support. 


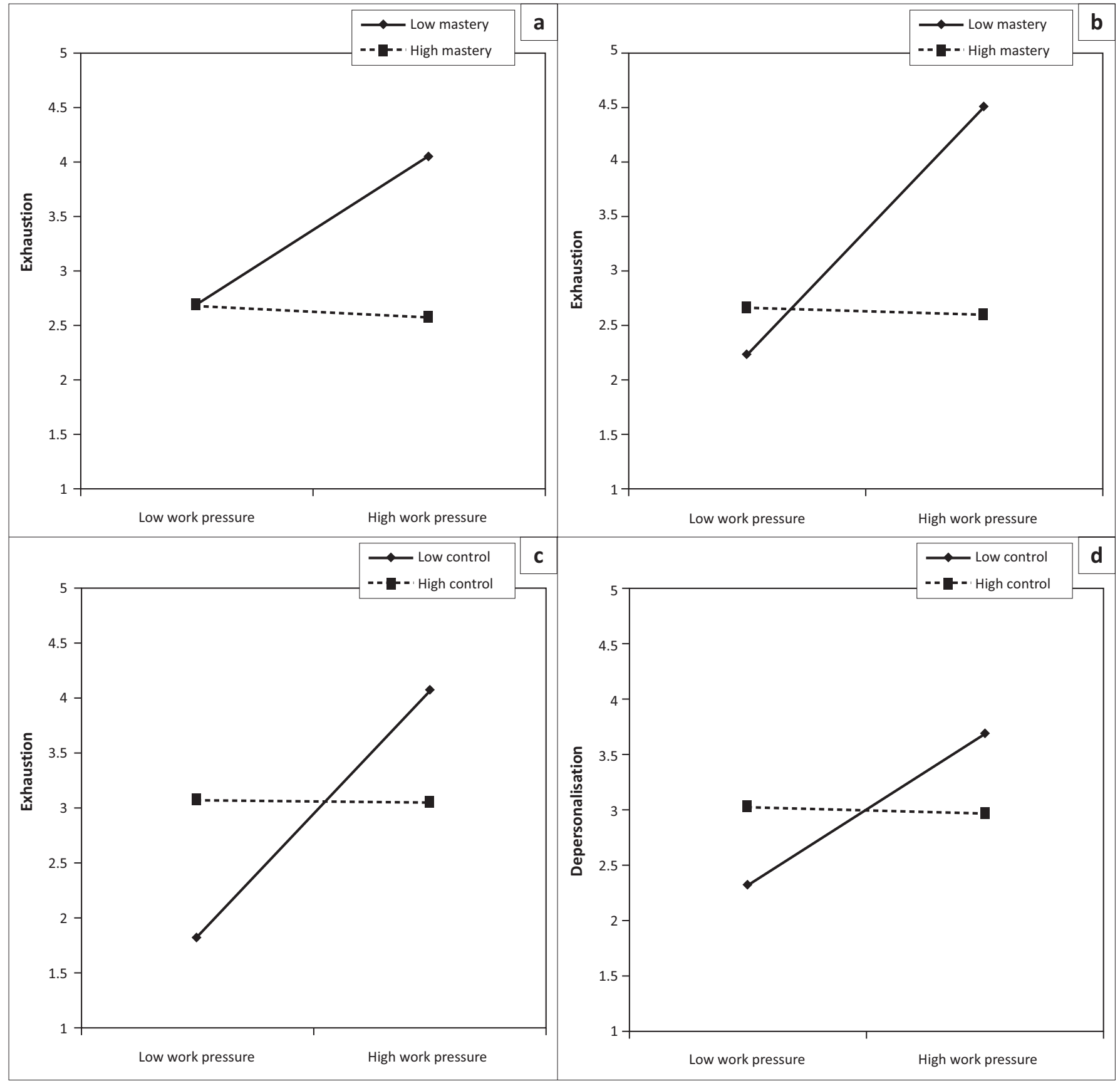

FIGURE 1: The four significant moderating effects plotted graphically.

This partially coincides with the findings of a longitudinal study by Van Vegchel et al. (2004) that a lack of social support predicts emotional exhaustion and depersonalisation. A longitudinal study by Burke, Greenglass and Schwarzer (1996) also found significant relationships between social support and the dimensions of burnout. The reasons for the non-significant relationship between autonomy and burnout and between social support and depersonalisation are unclear and should be further investigated. Baron and Kenny (1986) suggest that it could prove meaningful to consider the presence of an unintended moderator when a researcher fails to prove a hypothesised relationship between a predictor and a criterion variable (i.e. if the relationship has been found to be significant in one setting but not in another).
Hypothesis 3 suggested that job demands will be negatively related to all four recovery strategies. This hypothesis was also partially confirmed. Work pressure was negatively associated with all four of the recovery strategies. Thus, when one is confronted with high work pressure, it is likely that one will experience feelings of low control, an inability to detach from one's work, little mastery and an inability to relax after work. This corresponds to some degree to the results of research by Sonnentag and Fritz (2007), which confirmed a negative relationship between work pressure and detachment from work, control during leisure time and relaxation. However, their results failed to substantiate a relationship between work pressure and mastery experiences. Similarly, in a study by Kinnunen et al. (2011), direct relationships between job demands and mastery and 
control during leisure time could not be established. In the current study emotional load did not significantly predict any of the four recovery strategies. Cognitive demands only predicted mastery experiences. This suggests that when one experiences cognitive demands at work, one may be inclined to make use of mastery experiences in one's non-work time in order to recover from work. Again, one may argue that the nature of work in academia is associated with cognitive demands. However, these demands may often be welcomed by this group of people as they naturally seek opportunities to receive intellectual challenge and stimulation. Mastery experience by nature is a process by which an individual requires the skills to cope with stressors over which he has no control (Ben-Zur, 2002). Therefore, the finding that cognitive demands are positively associated with mastery might not be surprising.

Hypothesis 4, which stated that job resources will be positively related to all four recovery strategies, was partially confirmed. According to the results, individuals who experience autonomy at work may tend to experience higher control over their leisure time, mastery and relaxation. However, autonomy was not associated with detachment from work. On the other hand, social support did contribute significantly to detachment. Thus, employees who receive support from their colleagues at work may find it easier to detach from their work after hours than those employees who do not experience social support at work. Social support did not significantly predict control, mastery and relaxation. Very little evidence from previous research exists to substantiate these findings. As suggested by Spoor, De Jonge and Hamers (2010), the relationship between job resources and recovery as well as its relationship with work-related outcomes is largely unexplored and future research to address this gap is essential. A possible explanation for the findings in this study is that job resources such as social support foster a positive affect and have been shown to reduce an individual's stress levels by allowing for unwinding after work, which in turn could promote psychological detachment from work (Bakker et al., 2005; Deci \& Ryan, 2000; Neely et al., 2006; Sheldon \& Elliot, 1999).

Hypothesis 5, which suggested that all four recovery strategies would be negatively related to exhaustion and depersonalisation, was partially confirmed. The results reveal that only one of the four recovery strategies is a significant predictor of burnout. It seems that when one makes use of mastery experiences as a recovery strategy, one may experience lower levels of exhaustion and depersonalisation. Previous research has yielded similar results regarding the relationship between mastery strategies and burnout (Sonnentag, Binnewies \& Mojza, 2010; Sonnentag \& Fritz, 2007; Sonnentag, Kuttler \& Fritz, 2010). Again, the argument can be made that the need for academia (i.e. the study population in this research) to engage in activities in which they might learn something might explain why a lack of mastery experiences might lead to increased burnout levels. Opportunities to learn new skills, as in the case of mastery experiences where individuals acquire the skills to cope with their workplace stressors (Ben-Zur, 2002), might serve as stimulating experiences and therefore do not deplete the individual's energy (i.e. contribute to exhaustion) or lead to negativity about their work (i.e. depersonalisation).

Hypothesis 6 was partially confirmed. To summarise the results from the moderated SEM, mastery was found to be a moderator in the relationship between emotional load and exhaustion, as well as between work pressure and exhaustion. Also, control during leisure time moderated the relationship between work pressure and exhaustion, and between work pressure and depersonalisation. More specifically, the results suggest that employees with low mastery experiences experienced higher exhaustion as a result of a high emotional load and as a result of work pressure. It can be argued that although both high emotional load and high work pressure may lead to high exhaustion levels (Bakker et al., 2005; De Beer, Rothmann \& Pienaar, 2012), when employees feel that they do not engage in activities that create a sense of competence they do not have the opportunity to increase their self-efficacy to feel more competent to deal with the stressful high emotional load and work pressure (Ben-Zur, 2002; Sonnentag \& Fritz, 2007). As a result of this they may feel less energised to deal with their emotional load and work pressure and may consequently have higher levels of exhaustion.

In addition to the above, the results further indicate that when individuals experience low control during leisure time, the influence of work pressure on exhaustion and depersonalisation is higher when compared to individuals who experience high control during leisure time. This result can be clarified by tapping into the nature of control, which is related to the extent to which an individual feels that they have control over which activity to pursue during leisure time (Sonnentag \& Fritz, 2007). When employees feel that they do not have free will during their leisure time, this may create a negative affect which may spill over into the work situation. When these individuals also experience high work pressure and as a result may feel they do not have control over their work, this may strengthen the feeling of a lack of control they experience because of low control during leisure time. Consequently, they may tend to have higher levels of exhaustion and depersonalisation.

This study adds to the body of literature on effort recovery in South Africa. Very little empirical research has been done in South Africa regarding the use and benefits of different recovery strategies and the results from this study proved to provide some insight into the role of recovery strategies in the stressor-strain relationship. Specifically, it is suggested that employees are encouraged to engage in recovery strategies that will reduce their burnout levels, especially in mastery experiences. Although the results in this study did not confirm all four recovery strategies as moderators in the relationship between job demands and burnout, this does not imply that recovery experiences are not important 
to combat burnout. As previous research has suggested, all four recovery experiences play a significant role in fostering employee well-being. For example, Siltaloppi et al. (2009) found that psychological detachment and mastery reduce the need for recovery, that relaxation is associated with lower exhaustion under high time demands and that both psychological detachment and mastery predict occupational well-being. In another study by Siltaloppi, Kinnunen, Feldt and Tolvanen (2011), the results suggested that employees engaging in all four recovery activities were less likely to experience job burnout.

Despite the interesting results discussed, this study is not without limitations. It is suggested that future research corroborate the results found in this study, specifically the moderating effects, amongst educators at tertiary institutions. It is recommended that such studies collect longitudinal data to establish the relationships between job characteristics, recovery strategies and burnout. Also, larger samples might present researchers with a better representation of educators at tertiary institutions. Furthermore, it is suggested that the unexpected results and specifically the non-significant findings for hypothesised relationships be further explored in future studies.

\section{Acknowledgements Competing interests}

The authors declare that they have no financial or personal relationships that may have inappropriately influenced them in writing this article.

\section{Authors' contributions}

All the authors of this article contributed to the conceptualisation of this study. C.E. (North-West University) was the primary author of the article and was mainly responsible for the review of the literature. K.M. (North-West University) was primarily responsible for the collection of the data and the description of the research method. L.T.d.B. (North-West University) conducted the statistical analysis and interpreted the results. The arguments included as part of the discussion were formed by collaboration between the authors.

\section{References}

Bakker, A.B., \& Demerouti, E. (2007). The Job Demands-Resources model: State of the art. Journal of Managerial Psychology, 22(3), 309-328. http://dx.doi. org/10.1108/02683940710733115

Bakker, A.B., Demerouti, E., De Boer, E., \& Schaufeli, W.B. (2003). Job demands and job resources as predictors of absence duration and frequency. Journal of Vocational Behavior, 62(2), 341-356. http://dx.doi.org/10.1016/ S0001-8791(02)00030-1

Bakker, A.B., Demerouti, E., \& Euwema, M. C. (2005). Job resources buffer the impact of job demands on burnout. Journal of Occupational Health Psychology, 10(2) 170-180. http://dx.doi.org/10.1037/1076-8998.10.2.170

Bakker, A.B., Demerouti, E., \& Schaufeli, W.B. (2003). Validation of the Maslach Burnout Inventory-General Survey: An internet study. Anxiety, Stress, and Coping, 15, 245-260. http://dx.doi.org/10.1080/1061580021000020716

Bakker, A.B., Demerouti, E., \& Schaufeli, W.B. (2005). The crossover of burnout and work engagement among working couples. Human Relations, 58(5), 661-689. http://dx.doi.org/10.1177/0018726705055967
Bakker, A.B., Demerouti, E., Taris, T., Schaufeli, W.B., \& Schreurs, P. (2003). A multi-group analysis of the job demands-resources model in four home care organizations. International Journal of Stress Management, 10(1), 16-38. http:// dx.doi.org/10.1037/1072-5245.10.1.16

Bakker, A.B., Demerouti, E., \& Verbeke, W. (2004). Using the job demands: Resources model to predict burnout and performance. Human Resource Management, 43(1), 83-104. http://dx.doi.org/10.1002/hrm.20004

Bakker, A.B., Van Der Zee, K.I., Lewig, K.A., \& Dollard, M.F. (2006). The relationship between the big five personality factors and burnout: A study among volunteer counsellors. The Journal of Social Psychology, 146(1), 31-50. http://dx.doi. org/10.3200/SOCP.146.1.31-50

Bandura, A. (1977). Self-efficacy: Toward a unifying theory of behavioral change. Psychological Review, 84(2), 191-215. http://dx.doi.org/10.1037/0033-295X.84. 2.191

Bandura, A. (1986). Social foundations of thought and action: A social cognitive theory. Englewood Cliffs, NJ: Prentice-Hall.

Bandura, A. (1997). Self-efficacy: The exercise of control. New York, NY: Freeman.

Baron, R.M., \& Kenny, D.A. (1986). The moderator-mediator variable distinction in social psychological research: Conceptual, strategic, and statistical considerations. Journal of Personality and Social Psychology, 51(6), 1173-1182. http://dx.doi. org/10.1037/0022-3514.51.6.1173

Ben-Zur, H. (2002). Coping, affect and aging: The roles of mastery and self-esteem. Personality and Individual Differences, 32(2), 357-372. http://dx.doi.org/10.1016/ S0191-8869(01)00031-9

Binnewies, C., Sonnentag, S., \& Mojza, E.J. (2009). Feeling recovered and thinking about the good sides of one's work. Journal of Occupational Health Psychology, 14(3), 243-256. http://dx.doi.org/10.1037/a0014933

Brosschot, J.F., Gerin, W., \& Thayer, J. (2006). The perseverative cognition hypothesis: A review of worry, prolonged stress-related physiological activation, and health Journal of Psychosomatic Research, 60(2), 113-124. http://dx.doi.org/10.1016/j. jpsychores.2005.06.074

Browne, M.W., \& Cudeck, R. (1992). Alternative ways of assessing model fit. Sociological Methods \& Research, 21(2), 230-258. http://dx.doi. org/10.1177/0049124192021002005

Bryman, A., \& Bell, E. (2003). Business research methods. Oxford, UK: Oxford University Press.

Burger, J.M. (1989). Negative reactions to increases in perceived personal control. Journal of Personality and Social Psychology, 56(2), 246-256. http://dx.doi. org/10.1037/0022-3514.56.2.246

Burke, R.J., Greenglass, E.R., \& Schwarzer, R. (1996). Predicting teacher burnout over time: Effects of work stress, social support, and self-doubts on burnout and its consequences. Anxiety, Stress, and Coping, 9(3), 261-275. http://dx.doi. org/10.1080/10615809608249406

Carlson, C.R., \& Holye, R.H. (1993). Efficacy of abbreviated progressive muscle relaxation training: A quantitative review of behavioral medicine research. Journal of Consulting and Clinical Psychology, 61(6), 1059-1067. http://dx.doi. org/10.1037/0022-006X.61.6.1059

Cole, M.S., Walter, F., Bedeian, A.G., \& O'Boyle, E.H. (2012). Job burnout and employee engagement: A meta-analytic examination of construct proliferation. Journal of Management, 38(5), 1550-1581. http://dx.doi.org/10.1177/0149206311415252

Cordes, C.L., Dougherty, T.W., \& Blum, M. (1997). Patterns of burnout among managers and professionals: A comparison of models. Journal of Organizational Behavior, 18(6), 685-701. http://dx.doi.org/10.1002/(SICI)10991379(199711)18:6\%3C685::AID-JOB817\%3E3.0.CO;2-U

De Beer, L., Rothmann, S. Jr, \& Pienaar, J. (2012). A confirmatory investigation of a job demands-resources model using a categorical estimator. Psychological Reports, 111(2), 528-544. http://dx.doi.org/10.2466/01.03.10.PRO.111.5.528-544

De Croon, E.M., Sluiter, J.K., Blonk, R.W.B., Broersen, J.P.J., \& Frings-Dresen, M.H.W. (2004). Stressful work, psychological job strain, and turnover: A 2-year prospective cohort study of truck drivers. Journal of Applied Psychology, 89(3), 442-454 cohort study of truck drivers. Journal of App
http://dx.doi.org/10.1037/0021-9010.89.3.442

De Jonge, J., \& Dormann, C. (2003). The DISC model: Demand-induced strain compensation mechanisms in job stress. In M.F. Dollard, H.R. Winefield, \& A.H. Winefield (Eds.), Occupational stress in the service professions (pp. 43-74). London, UK: Taylor \& Francis. http://dx.doi.org/10.1016/S0304-3800(02)00280-6

Deci, E.L., \& Ryan, R.M. (2000). The "what" and "why" of goal pursuits: Human needs and the self-determination of behavior. Psychological Inquiry, 11(4), 227-268. http://dx.doi.org/10.1207/S15327965PLI1104_01

Demerouti, E., Bakker, A.B., Geurts, S.A.E., \& Taris, T.W. (2009). Daily recovery from work-related effort during non-work time. In S. Sonnentag, P.L. Perrewé, \& D.C. Ganster (Eds.), Current perspectives on job-stress recovery: Research in occupational stress and well being (Vol. 7, pp. 85-123). Bingley, UK: JAI Press.

Demerouti, E., Bakker, A.B., Nachreiner, F., \& Schaufeli, W.B. (2001). The job demandsresources model of burnout. Journal of Applied Psychology, 86(3), 499-512. http://dx.doi.org/10.1037/0021-9010.86.3.499

Demsky, C.A. (2012). Interpersonal conflict and employee well-being: The moderating role of recovery experiences. Unpublished master's dissertation, Department of Psychology, Portland State University, Portland, OR.

Denollet, J., \& De Vries, J. (2006). Positive and negative affect within the realm of depression, stress and fatigue: The two-factor distress model of the Global Mood Scale (GMS). Journal of Affective Disorders, 91(2), 171-180. http://dx.doi. org/10.1016/j.jad.2005.12.044

Eden, D. (2001). Vacations and other respites: Studying stress on and off the job. In C.L. Cooper, \& I.T. Robertson (Eds.), International review of industrial and organizational psychology (pp. 121-146). Chichester, UK: Wiley. 
Elfering, A., Grebner, S., Semmer, N.K., \& Gerber, H. (2002). Time control, catecholamines, and back pain among young nurses. Scandinavian Journal of Work, Environment \& Health, 28(6), 386-393. http://dx.doi.org/10.5271/ of Work,

Etzion, D., Eden, D., \& Lapidot, Y. (1998). Relief from job stressors and burnout: Reserve service as a respite. Journal of Applied Psychology, 83(4), 577-585. http://dx.doi. org/10.1037/0021-9010.83.4.577

Evers, W., \& Tomic, W. (2003). Burnout among Dutch Reformed pastors. Journal of Psychology and Theology, 31(4), 329-338.

Fritz, C., Sonnentag, S., Spector, P.E., \& McInroe, J.A. (2010). The weekend matters: Relationships between stress recovery and affective experiences. Journal of Organizational Behavior, 31(8), 1137-1162. http://dx.doi.org/10.1002/ job.672

Frone, M.R., Russell, M., \& Cooper, M.L. (1995). Job stressors, job involvement and employee health: A test of identity theory. Journal of Occupational and Organizational Psychology, 68(1), 1-11. http://dx.doi org/10.1111/j.2044-8325.1995.tb00684.x

Geurts, S.A.E., \& Sonnentag, S. (2006). Recovery as an explanatory mechanism in the relation between acute stress reactions and chronic health impairment Scandinavian Journal of Work, Environment \& Health, 32(6), 482-492. http:// dx.doi.org/10.5271/sjweh.1053

González-Romá, V., Schaufeli, W.B., Bakker, A.B., \& Lloret, S. (2006). Burnout and work engagement: Independent factors or opposite poles? Journal of Vocational Behavior, 62(1), 165-174. http://dx.doi.org/10.1016/j.jvb.2005.01.003

Grossman, P., Niemann, L., Schmidt, S., \& Walach, H. (2004). Mindfulness-based stress reduction and health benefits: A meta-analysis. Journal of Psychosomatic Research, 57(1), 35-43. http://dx.doi.org/10.1016/S0022-3999(03)00573-7

Hackman, J.R., \& Oldham, G.R. (1975). Development of the Job Diagnostic Survey. Journal of Applied Psychology, 60(2),159-170. http://dx.doi.org/10.1037/ h0076546

Hackman, J.R., \& Oldham, G.R. (1976) Motivation through the design of work: Test of a theory. Organizational Behaviour and Human Performance, 16(2), 250-279. http://dx.doi.org/10.1016/0030-5073(76)90016-7

Hakanen, J., Bakker, A.B., \& Schaufeli, W.B. (2006). Burnout and work engagement among teachers. Journal of School Psychology, 43(6), 495-513. http://dx.doi. org/10.1016/j.jsp.2005.11.001

Hakanen, J.J., Schaufeli, W.B., \& Ahola, K. (2008). The Job Demands-Resources model: A three-year cross-lagged study of burnout, depression, commitment, and work engagement. Work \& Stress, 22(3), 224-241. http://dx.doi. org/10.1080/02678370802379432

Halbesleben, J.R.B., Wheeler, A.R., \& Paustian-Underdahl, S.C. (2013). The Impact of furloughs on emotional exhaustion, self-rated performance, and recovery experiences. Journal of Applied Psychology, 98(3), 492-503. http://dx.doi org/10.1037/a0032242

Hartig, T., Evans, G.W., Jamner, L.D., Davis, D.S., \& Gärling, T. (2003). Tracking restoration in natural and urban field settings. Journal of Environmental Psychology, 23(2), 109-123. http://dx.doi.org/10.1016/S0272-4944(02)00109-3

Hobfoll, S.E. (1998). Stress, culture, and community: The psychology and philosophy of stress. New York, NY: Plenum. http://dx.doi.org/10.1007/978-1-4899-0115-6

Hobfoll, S.E. (2001). The influence of culture, community, and the nested-self in the stress process: Advancing conservation of resources theory. Applied Psychology: An International Review, 50(3), 337-370. http://dx.doi.org/10.1111/14640597.00062

Hockey, G.R.J. (2000). Work environments and performance. In N. Chmiel (Ed.), Introduction to work and organizational psychology: A European perspective (pp. 206-230). Malden, MA: Blackwell.

Hockey, R. (1996). Skilled performance and mental workload. In P. Warr (Ed.), Psychology at work (4th edn., pp. 13-39). London, UK: Penguin.

Hoyle, R.H. (1995). Structural equation modeling: Concepts, issues, and applications. Thousand Oaks, CA: Sage Publications Inc.

Hu, L., \& Bentler, P.M. (1998). Fit indices in covariance structure modeling: Sensitivity to underparameterized model misspecification. Psychological Methods, 3(4) 424-453. http://dx.doi.org/10.1037/1082-989X.3.4.424

Jacobson, E. (1938). Progressive relaxation. (2nd edn.). Chicago, IL: University of Chicago Press.

Jansen, N.W.H., Kant, I.J., \& Van den Brandt, P.A. (2002). Need for recovery in the working population: Descriptions and associations with fatigue and psychological distress. International Journal of Behavioral Medicine, 9(4), 322-340. http:// dx.doi.org/10.1207/S15327558IJBM0904_03

Kim, H., \& Stoner, M. (2008). Burnout and turnover intention among social workers: Effects of role stress, job autonomy and social support. Administration in Socia Work, 32(3), 5-25. http://dx.doi.org/10.1080/03643100801922357

Kinnunen, U., Feldt, T., Siltaloppi, M., \& Sonnentag, S. (2011). Job demands-resources model in the context of recovery: Testing recovery experiences as mediators. European Journal of Work and Organizational Psychology, 20(6), 805-832. http:// dx.doi.org/10.1080/1359432X.2010.524411

Kinnunen, U., Mauno, S., \& Siltaloppi, M. (2010). Job insecurity, recovery and wellbeing at work: Recovery experiences as moderators. Economic and Industria Democracy, 31, 179-194. http://dx.doi.org/10.1177/0143831X09358366

Lawson, D.A., \& O'Brien, R.M. (1994). Behavioral and self-report measures of staff burnout in developmental disabilities. Journal of Organizational Behavio Management, 14(2), 37-54. http://dx.doi.org/10.1300/J075v14n02_04

Le Blanc, P.M., Bakker, A.B., Peeters, M.C., Van Heesch, N.C., \& Schaufeli, W. B. (2001). Emotional job demands and burnout among oncology care providers.
Anxiety, Stress and Coping, 14(3), 243-263. http://dx.doi.org/10.1080/ 10615800108248356

Llorens, S., Bakker, A., Schaufeli, W.B. \& Salanova, M. (2006). Testing the robustness of the Job Demands-Resources model. International Journal of Stress Management, 13(3), 378-391. http://dx.doi.org/10.1037/1072-5245.13.3.378

Lounsbury, L.W., \& Hoopes, L.L. (1986). A vacation from work: Changes in work and nonwork outcomes. Journal of Applied Psychology, 71(3), 392-401. http://dx.doi. org/10.1037/0021-9010.71.3.392

Lovibond, S.H., \& Lovibond, P.F. (1996). Depression anxiety stress scales. Sydney, Australia: The Psychology Foundation of Australia Inc.

Lumsden, D.P. (1981). Is the concept of "stress" of any use, anymore. Contributions to primary prevention in mental health: Working papers. Toronto, Canada: Toronto National Office of the Canadian Mental Health Association.

Marsh, H.W. (2007). Application of confirmatory factor analysis and structural equation modeling in sport/exercise psychology. In G. Tenenbaum, \& R.C. Eklund (Eds.), Handbook of sport psychology (3rd edn., pp. 774-798). New York, NY: (Eds.), Handbook of sport psychology (3rd edn., pp.
Wiley. http://dx.doi.org/10.1080/10705510701303921

Marsh, H.W., Hau, K.T., \& Grayson, D. (2005). Goodness of fit evaluation in structural equation modeling. In A. Maydeu-Olivares, \& J. McCardle (Eds.), Psychometrics: A Festschrift to Roderick P. McDonald (pp. 320-341). Hillsdale, NJ: Erlbaum.

Martin, A.M. (2010). Predictors of burnout and self-efficacy among special education teachers. Doctoral thesis, Teachers College, Columbia University, United States of America. Available from ProQuest Dissertations and Theses database.

Maslach, C., \& Jackson, S.E. (1981). The measurement of experienced burnout. Journal of Organizational Behavior, 2(2), 99-113. http://dx.doi.org/10.1002/ job.4030020205

Maslach, C., \& Jackson, S.E. (1986). Maslach Burnout Inventory Manual. (2nd edn.) Palo Alto, CA: Consulting Psychologists Press.

Maslach, C., Schaufeli, W.B., \& Leiter, M.P. (2001). Job burnout. Annual Review of Psychology, 52(1), 397-422. http://dx.doi.org/10.1146/annurev.psych.52.1.397

Meijman, T.F. (1989). Mentale Belasting en werkstress: Een arbeidspsychologische benadering [Mental workload and job stress: A work psychological approach]. Assen/Maastricht, The Netherlands: Van Gorcum.

Meijman, T.F., \& Mulder, G. (1998). Psychological aspects of workload. In P.J. Drenth, H. Thierry, \& C.J. de Wolff (Eds.), Handbook of work and organizational psychology (Vol. 2, pp. 5-33). Hove, UK: Psychology Press.

Morris, J.A., \& Feldman, D.C. (1996). The dimensions, antecedents, and consequences of emotional labor. Academy of Management Review, 21(4), 986-1010. http:// dx.doi.org/10.5465/AMR.1996.9704071861

Muthén, L.K., \& Muthén, B.O. (2012). Mplus user's guide. (7th edn.). Los Angeles, CA: Muthén \& Muthén.

Neely, L.C., Lakey, B., Cohen, J.L., Barry, R., Orehek, E., Abeare, C.A. et al. (2006) Trait and social processes in the link between social support and affect: An experimental, laboratory investigation. Journal of Personality, 74(4), 1015-1045. http://dx.doi.org/10.1111/j.1467-6494.2006.00401.x

Pan, Y., \& Jackson, R.T. (2008). Ethnic difference in the relationship between acute inflammation and serum ferritin in US adult males. Epidemiology and Infection 136, 421-431. http://dx.doi.org/10.1017/S095026880700831X

Parkinson, B., \& Totterdell, P. (1999). Classifying affect regulation strategies. Cognition and Emotion, 13(3), 277-303. http://dx.doi.org/10.1080/026999399379285

Pearlin, L., \& Schooler, C. (1978). The structure of coping. Journal of Health and Social Behavior, 19(1), 2-21. http://dx.doi.org/10.2307/2136319

Peeters, A.G., \& Rutte, C.G. (2005). Time management behavior as a moderator for the job demand-control interaction. Journal of Occupational Health Psychology, 10(1), 64-75. http://dx.doi.org/10.1037/1076-8998.10.1.64

Peeters, M.C.W., Montgomery, A.J., Bakker, A.B., \& Schaufeli, W.B. (2005). Balancing work and home: How job and home demands are related to burnout. International Journal of Stress Management, 12(1), 43-61. http://dx.doi.org/10.1037/1072 5245.12.1.43

Pelletier, C.L. (2004). The effect of music on decreasing arousal due to stress: A meta-analysis. Journal of Music Therapy, 41(3), 192-214. http://dx.doi. org/10.1093/jmt/41.3.192

Peterson, C., \& Seligman, M.E.P. (1984). Causal explanations as a risk factor for depression: Theory and evidence. Psychological Review, 91(3), 347-374. http:// dx.doi.org/10.1037/0033-295X.91.3.347

Price, L., \& Spence, S.H. (1994). Burnout symptoms amongst drug and alcohol service employees: Gender differences in the interaction between work and home stressors. Anxiety, Stress and Coping, 7(1), 67-84.

Raykov, T. (2012). Scale construction and development using structural equation modeling. In R.H. Hoyle (Ed.), Handbook of structural equation modeling (pp. 472-492). New York, NY: Guilford Press. http://dx.doi.org/10.1080/10705511.2 012.687660

Rogerson, P.A. (2001). Statistical methods for geography. London, UK: Sage.

Rotter, J. (1966). Generalized expectancies for internal versus external control of reinforcement. Psychological Monographs, 80(1), 1-28. http://dx.doi. org/10.1037/h0092976

Sarason, I.G., Levine, H.M., Basham, R.B., \& Sarason, B.R. (1983). Assessing social support: The social support questionnaire. Journal of Personality and Social Psychology, 44(1), 127-139. http://dx.doi.org/10.1037/0022-3514.44.1.127

Schaufeli, W.B., \& Bakker, A.B. (2004). Job demands, job resources, and their relationship with burnout and engagement: A multi-sample study. Journal of Organizational Behavior, 25(3), 293-315. http://dx.doi.org/10.1002/job.248 
Schaufeli, W.B., \& Enzmann, D. (1998). The burnout companion to study and practice: A critical analysis. London, UK: Taylor \& Francis.

Schaufeli, W.B., \& Taris, T.W. (2005). The conceptualization and measurement of burnout: Common ground and worlds apart. Work \& Stress, 19(3), 256-262. http://dx.doi.org/10.1080/02678370500385913

Schroër, C.A.P. (1997). De toename van arbeidsongeschiktheid wegens psychische aandoeningen [The increase of work disability due to mental disorders]. Tijdschrift voor Bedrijfs- en Verzekeringsgeneeskunde, 5(1), 16-23.

Schulz, R., \& Heckhausen J. (1996). A life span model of successful aging. American Psychologist, 51(7), 702-714. http://dx.doi.org/10.1037/0003-066X.51.7.702

Seeman, M. (1983). Alienation motifs in contemporary theorizing: The hidden continuity of the classic themes. Social Psychology Quarterly, 46(3), 171-184. http://dx.doi.org/10.2307/3033789

Shapiro, D.H., Schwartz, C.E., \& Astin, J. (1996). Controlling ourselves, controlling our world: Psychology's role in understanding positive and negative consequences of seeking and gaining control. American Psychologist, 51(12), 1213-1230. http:// dx.doi.org/10.1037/0003-066X.51.12.1213

Sheldon, K.M., \& Elliot, A.J. (1999). Goal striving, need-satisfaction, and longitudina well-being: The self-concordance model. Journal of Personality and Socia Psychology, 76(3), 482-497. http://dx.doi.org/10.1037/0022-3514.76.3.482

Shin, H.S., Han, H.R., \& Kim, M.T. (2007). Predictors of psychological well-being amongst Korean immigrants to the United States: A structured interview survey. International Journal of Nursing studies, 44(3), 415-426. http://dx.doi. org/10.1016/j.ijnurstu.2006.04.007

Sijtsma, K. (2009). Reliability beyond theory and into practice. Psychometrika, 74(1) 169-173. http://dx.doi.org/10.1007/s11336-008-9103-y

Siltaloppi, M., Kinnunen, U., \& Feldt, T. (2009). Recovery experiences as moderators between psychosocial work characteristics and occupational well-being. Work \& Stress, 23(4), 330-348. http://dx.doi.org/10.1080/02678370903415572

Siltaloppi, M., Kinnunen, U., Feldt, T., \& Tolvanen, A. (2011). Identifying patterns of recovery experiences and their links to psychological outcomes across one year. International Archives of Occupational and Environmental Health, 84(8), 877-888. $\mathrm{http}: / / \mathrm{dx}$.doi.org/10.1007/s00420-011-0672-1

Sluiter, J.K., De Croon, E.M., Meijman, T.F., \& Frings-Dresen, M.H. (2003). Need for recovery from work related fatigue and its role in the development and prediction of subjective health complaints. Occupational and Environmental Medicine, 60(1), 62-70. http://dx.doi.org/10.1136/oem.60.suppl_1.i62

Sluiter, J.K., Van der Beek, A.J., \& Frings-Dresen, M.H.W. (1999). The influence of work characteristics on the need for recovery and experienced health A study on coach drivers. Ergonomics, 42(4), 573-583. http://dx.doi. org/10.1080/001401399185487

Sonnentag, S. (2003). Recovery, work engagement, and proactive behavior: A new look at the interface between non-work and work. Journal of Applied Psychology, 88(3), 518-528. http://dx.doi.org/10.1037/0021-9010.88.3.518

Sonnentag, S., \& Bayer, U.V. (2005). Switching off mentally: Predictors and consequences of psychological detachment from work during off-job time. Journal of Occupational Health Psychology, 10(4), 393-414. http://dx.doi. org/10.1037/1076-8998.10.4.393

Sonnentag, S., \& Fritz, C. (2007). The recovery experience questionnaire: Development and validation of a measure for assessing recuperation and unwinding from work. Journal of Occupational Health Psychology, 12(3), 204-221. http://dx.doi. org/10.1037/1076-8998.12.3.204

Sonnentag, S., Binnewies, C., \& Mojza, E.J. (2008). Did you have a nice evening? A day-level study on recovery experiences, sleep, and affect. Journal of Applied Psychology, 93(3), 674-684. http://dx.doi.org/10.1037/0021-9010.93.3.674

Sonnentag, S., Binnewies, C.J., \& Mojza, E.J. (2010). Staying well and engaged when demands are high: The role of psychological detachment. Journal of Applied Psychology, 95(5), 965-976. http://dx.doi.org/10.1037/a0020032

Sonnentag, S., \& Fritz, C. (2014). Recovery from job stress: The stressor-detachment model as an integrative framework. Journal of Organizational Behavior, 36(1), 72-103.
Sonnentag, S., Kuttler, I., \& Fritz, C. (2010). Job stressors, emotional exhaustion, and need for recovery: A multi-source study on the benefits of psychological detachment. Journal of Vocational Behavior, 76(3), 355-365. http://dx.doi. org/10.1016/j.jvb.2009.06.005

Sonnentag, S., Unger, D., \& Nägel, I.J. (2013). Workplace conflict and employee well-being: The moderating role of detachment from work during off-job time. International Journal of Conflict Management, 24(2), 166-183. http://dx.doi. org/10.1108/10444061311316780

Sonnentag, S., \& Zijlstra, F.R.H. (2006). Job characteristics and off-job activities as predictors of need for recovery, well-being, and fatigue. Journal of Applied Psychology, 91(2), 330-350. http://dx.doi.org/10.1037/0021-9010.91.2.330

Spoor, E., De Jonge, J., \& Hamers, J.P.H. (2010). Design of the DIRECT-project: Interventions to increase job resources and recovery opportunities to improve job-related health, well-being, and performance outcomes in nursing homes. BMC Public Health, 10, 293-302. http://dx.doi.org/10.1186/1471-2458-10-293

Stone, A.A., Kennedy-Moore, E., \& Neale, J.M. (1995). Association between daily coping and end-of-day mood. Health Psychology, 14(4), 341-349. http://dx.doi. org/10.1037/0278-6133.14.4.341

Taris, T.W., Peeters, M.C.W., Le Blanc, P.M., Schreurs, P.J.G., \& Schaufeli, W.B. (2001) From inequity to burnout: The role of job stress. Journal of Occupational Health Psychology, 6(4), 303-323. http://dx.doi.org/10.1037/1076-8998.6.4.303

Taylor, S.E. (1983). Adjustment to threatening events: A theory of cognitive adaptation. American Psychologist, 38(11), 1161-1173. http://dx.doi.org/10.1037/0003066X.38.11.1161

Taylor, S.E., \& Brown, J.D. (1988). Illusion and well-being: A social psychological perspective on mental health. Psychological Bulletin, 103(2), 193-210. http:// dx.doi.org/10.1037/0003-066X.38.11.1161

Thompson, S., \& Spacapan, S. (1991). Perceptions of control in vulnerable populations. Journal of Social Issues, 47(4), 1-21. http://dx.doi.org/10.1111/j.1540-4560.1991. tb01831.x

Van der Klink, J.J.L., Blonk, R.W.B., Schene, A.H., \& Van Dijk, F.J.H. (2001). The benefits of interventions for work-related stress. American Journal of Public Health, 91(2), 270-276. http://dx.doi.org/10.2105/AJPH.91.2.270

Van Hooff, M.L.M., Geurts, S.A.E., Kompier, M.A.J., \& Taris, T.W. (2007). Workdays, in-between workdays and the weekend: A diary study on effort and recovery. International Archives of Occupational and Environmental Health, 80(7), 599-630. http://dx.doi.org/10.1007/s00420-007-0172-5

Van Vegchel, N., De Jonge, J., Soderfeldt, M., Dormann, C., \& Schaufeli, W.B. (2004) Quantitative versus emotional demands among Swedish human services employees: Moderating effects of job control and social support. International Journal of Stress Management, 11(1), 21-40. http://dx.doi.org/10.1037/1072-5245.11.1.21

Vrijkotte, T.G., Van Doornen, L.J., \& De Geus, E.J. (2000). Effects of work stress on ambulatory blood pressure, heart rate, and heart rate variability. Hypertension, 35(4), 880-886. http://dx.doi.org/10.1161/01.HYP.35.4.880

Weiner, B., \& Kukla, A. (1970). An attributional analysis of achievement motivation Journal of Personality and Social Psychology, 15(1), 1-20. http://dx.doi. org/10.1037/h0029211

Westman, M., \& Eden, D. (1997). Effects of a respite from work on burnout: Vacation relief and fade-out. Journal of Applied Psychology, 82(4), 516-257. http://dx.doi. org/10.1037/0021-9010.82.4.516

Westman, M., \& Etzion, D. (2001). The impact of vacation and job stress on burnout and absenteeism. Psychology and Health, 16(5), 595-606. http://dx.doi. org/10.1080/08870440108405529

Xanthopoulou, D., Bakker, A.B., Demerouti, E., \& Schaufeli, W.B. (2009). Reciprocal relationships between job resources, personal resources, and work engagement. Journal of Vocational Behavior, 74(3), 235-244. http://dx.doi.org/10.1016/j. jvb.2008.11.003

Zijlstra, F.R.H. (1996). Effort as energy regulation. In W. Battmann, \& S. Dutke (Eds.), Processes of the molar regulation of behavior (pp. 219-235). Lengerich, Germany: Pabst.

Zohar, D., Tzischinski, O., \& Epstein, R. (2003). Effects of energy availability on immediate and delayed emotional reactions to work events. Journal of Applied Psychology, 88(6), 1082-1093. http://dx.doi.org/10.1037/0021-9010.88.6.1082 